\title{
Effects of warming and grazing on dissolved organic nitrogen in a Tibetan alpine meadow ecosystem
}

Jiang, Lili; Wang, Shiping; Luo, Caiyun; Zhu, Xiaoxue; Kardol, Paul; Zhang, Zhenhua; Li, Yaoming; Wang, Changshun; Wang, Yanfen; Jones, David

\section{Soil \& Tillage Research}

DOI:

10.1016/j.still.2015.12.012

Published: 01/05/2016

Peer reviewed version

Cyswllt i'r cyhoeddiad / Link to publication

Dyfyniad o'r fersiwn a gyhoeddwyd / Citation for published version (APA):

Jiang, L., Wang, S., Luo, C., Zhu, X., Kardol, P., Zhang, Z., Li, Y., Wang, C., Wang, Y., \& Jones, D. (2016). Effects of warming and grazing on dissolved organic nitrogen in a Tibetan alpine meadow ecosystem. Soil \& Tillage Research, 158(May), 156-164.

https://doi.org/10.1016/j.still.2015.12.012

\footnotetext{
Hawliau Cyffredinol / General rights

Copyright and moral rights for the publications made accessible in the public portal are retained by the authors and/or other copyright owners and it is a condition of accessing publications that users recognise and abide by the legal requirements associated with these rights. study or research

- Users may download and print one copy of any publication from the public portal for the purpose of private

- You may not further distribute the material or use it for any profit-making activity or commercial gain

- You may freely distribute the URL identifying the publication in the public portal?
}

Take down policy

If you believe that this document breaches copyright please contact us providing details, and we will remove access to the work immediately and investigate your claim. 
1 Warming and grazing directly influence dissolved organic nitrogen in a Tibetan

2 alpine meadow ecosystem

3 Lili Jiang $\bullet$ Caiyun Luo $\bullet$ Shiping Wang $\bullet$ Zhenhua Zhang $\bullet$ Xiaoxue Zhu $\bullet$ Yaoming

4 Li • Changshun Wang • Yanfen Wang • Paul Kardol • Davey L. Jones

$6 \quad$ Lili Jiang $(*) \cdot$ Shiping Wang $・$ Yaoming Li $\bullet$ Changshun Wang

7 Key Laboratory of Alpine Ecology and Biodiversity, Chinese Academy of Sciences,

8 Institute of Tibetan Plateau Research, Chinese Academy of Sciences, Beijing 100101,

9 China

10 Caiyun Luo $\bullet$ Zhenhua Zhang $\bullet$ Xiaoxue Zhu

11 Key Laboratory of Adaptation and Evolution of Plateau Biota, Northwest Institute of

12 Plateau Biology, Chinese Academy of Sciences, Xining 810008, China

13 Yanfen Wang

14 College of Life Sciences and Biological Technology, University of Chinese Academy

15 of Sciences, Beijing 100049, China

16 Paul Kardol

17 Department of Forest Ecology and Management, Swedish University of Agricultural

18 Sciences, 90183 Umeå, Sweden

19 Davey L. Jones

20 School of Environment, Natural Resources and Geography, Bangor University,

21 Gwynedd LL57 2UW, UK 
23 Original article

$24 *$ Corresponding Author

25 L.L Jiang

26 Key Laboratory of Alpine Ecology and Biodiversity, Institute of Tibetan Plateau

27 Research, Chinese Academy of Sciences, Beijing 100101, China

28 Tel.: +86 10 84097096; fax: +86 1084097092

29 E-mail address: 1ljiang@itpcas.ac.cn

30 Lili Jiang and Caiyun Luo contributed equally to this paper 31 
32 Abstract The conversion of insoluble organic nitrogen $(\mathrm{N})$ to dissolved organic $\mathrm{N}$ 33 (DON) is a major constraint to the supply of $\mathrm{N}$ to plants, possibly even more so than the conversion of DON to inorganic $\mathrm{N}\left(\mathrm{NH}_{4}{ }^{+}\right.$and $\left.\mathrm{NO}_{3}{ }^{-}\right)$. The production and fate of inorganic $\mathrm{N}$ as regulated by environmental change are relatively well understood, but we know comparatively little about how these factors influence DON. We measured total N, DON and dissolved inorganic nitrogen (DIN) concentrations in the soil solution and plant $\mathrm{N}$ uptake in a factorial warming $\times$ grazing experiment in a Tibetan alpine meadow. Results showed that warming significantly decreased DON concentration by up to $36 \%$. Warming effects on DON were to some extent dependent on the grazing treatment, and varied with soil depth and sampling date. Grazing increased soil DON, opposite to the effect of warming. Previous studies have found warming to increase a range of factors which contribute to the supply of DON in soil; our results suggest that the observed decrease in DON under warming could be ascribed to an acceleration of soil DON turnover, greater microbial $\mathrm{N}$ immobilization and enhanced plant $\mathrm{N}$ uptake. In conclusion, this study highlights the complex interaction of land management regime and climate warming in the regulation of DON cycling in N-limiting environments.

Keywords Alpine meadow $\cdot$ dissolved organic nitrogen $\bullet$ plant $\mathbf{N}$ uptake $\cdot$ nitrogen cycling • progressive $\mathrm{N}$ limitation $\bullet$ global warming 


\section{Introduction}

The availability of inorganic nitrogen $(\mathrm{N})$ has traditionally been considered the primary constraint on vegetation productivity in terrestrial ecosystems (Vitousek and Howarth, 1991; Elser et al., 2007; LeBauer and Treseder, 2008). However, increasing studies have shown that the conversion of insoluble organic $\mathrm{N}$ to dissolved organic nitrogen (DON) can also be a major constraint on the supply of $\mathrm{N}$ to plants (Jones et al., 2005; Jan et al., 2009; Jones et al., 2009; Farrell et al., 2011). The production and fate of inorganic $\mathrm{N}$ as regulated by environmental factors, such as temperature and land use are relatively well understood (Wu et al., 2011; Bai et al., 2013; Ueda et al., 2013), but relatively few studies have been carried out on how these factors affect DON, especially in alpine ecosystems.

DON concentrations in soil are regulated by a range of factors and represent the net balance between input and removal processes (Fig 1). Soil DON mainly arises from plant and microbial turnover and root exudation (Chapman et al., 2001; Jones et al., 2004; Haynes, 2005; Christou et al., 2006). Similarly, there is increasing evidence suggesting that plant roots can directly remove DON from soil solution (Jones et al., 2004; Jones et al., 2005; Xu et al., 2006; Jämtgård et al., 2008; Xu et al., 2011). DON, however, also represents an important source of $\mathrm{C}$ and $\mathrm{N}$ for soil microorganisms and is an important precursor leading to the production of $\mathrm{NH}_{4}{ }^{+}$and $\mathrm{NO}_{3}{ }^{-}$in soil (Bardgett et al., 2003; Butler et al., 2012; Bai et al., 2013) (Fig. 1). Previous studies have shown inconsistent effects of warming on DON. For example, some experiments show positive effects as warming accelerates litter decomposition (Kalbitz et al., 2004), while others demonstrate negative effects in forests, perhaps due to higher mineralization rates (Huang and Schoenau, 1998; Ueda et al., 2013). Using elevation as a proxy of climate, results indicate that plants preferentially utilized DON over 
inorganic $\mathrm{N}$ in a cold-temperate forest ecosystem (Averill and Finzi, 2011). Shan et al. (2014) found that a component of the DON pool (e.g. amino acids) increased with altitude. Variation in altitude, however, led to marked changes not only in temperature, but also factors such as moisture and vegetation composition which makes interpretation of the results difficult. To date, there have no direct, in situ measurements of DON dynamics under elevated temperature.

DON includes two functional pools: high molecular weight DON (e.g. polyphenol-bound protein-N that is recalcitrant and prone to precipitation) and low molecular weight DON which is highly bioavailable (e.g. amino acids, peptides). Current evidence suggests that with the exception of inorganic N, plant roots or soil microorganism only possess the capacity to directly take up and assimilate low molecular weight DON (Yu et al., 2002; Jones et al., 2004). Further, direct uptake of soil amino acids by plants has been demonstrated in a range of ecosystems including cold forest (Persson et al., 2003), arctic tundra (Kielland, 1994; Nordin et al., 2004), temperate grassland (Weigelt et al., 2005), and Tibet alpine meadow ecosystems (Xu et al., 2006; Xu et al., 2011).

Grazing has been shown to decrease soil DON through the stimulation of net $\mathrm{N}$ mineralization and nitrification (Groffmann et al., 1993; Frank et al., 2000; Le Roux et al., 2003; Hu et al., 2010). For low productivity ecosystems, however, the opposite effects of grazing have been observed, showing a decrease in net $\mathrm{N}$ mineralization (Stark et al., 2000; Harrison et al., 2004; Holst et al., 2007). In alpine meadows, previous results have shown that grazing may stimulate the production of DON as it increased above- and below-ground plant biomass production (Hu et al., 2010; Wang et al., 2012) and increased rates of litter decomposition (Luo et al., 2010), while warming did not affect net $\mathrm{N}$ mineralization rates (Wang et al., 2012). We 
hypothesize that concentrations of DON will increase under grazing in alpine meadows.

Tibetan alpine meadows are unique ecosystems which are particularly sensitive to global climate change; the average surface temperature in Tibet is expected to increase $2^{\circ} \mathrm{C}$ more than the global average by 2050 (Wang and French, 1994; Thompson et al., 2000; Giorgi et al., 2001). Grazing is the main land use for alpine meadows, and it is expected that grazing pressure will substantially increase in the near future due to the rise in human population within the region (Wiener et al., 2003; Yao et al., 2006). Here, we conducted a field experiment to test the effects of warming and grazing on soil DON dynamics in Tibetan alpine meadows. First, we tested the hypothesis that warming decreases soil DON. This could result from greater demand of DON for plant biomass production (Xu et al., 2006; Wang et al., 2012). Second, we tested the hypothesis that grazing will increase soil DON as we previously found that warming increased above- and below-ground plant biomass production ( $\mathrm{Hu}$ et al., 2010; Wang et al., 2012) and increased rates of litter decomposition (Luo et al., 2010), while warming did not affect net $\mathrm{N}$ mineralization rates (Wang et al., 2012).

\section{Materials and methods}

\section{Experimental site}

The experimental site is located at the Haibei Alpine Meadow Ecosystem Research Station $\left(37^{\circ} 37^{\prime} \mathrm{N}, 101^{\circ} 12^{\prime} \mathrm{E}\right)$, a facility run by the Northwest Institute of Plateau Biology, Chinese Academy of Sciences. The station lies in the northeastern part of the 
Qinghai-Tibet plateau in a large valley surrounded by the Qilian Mountains. The mean elevation of the valley bottom is $3200 \mathrm{~m}$ and experiences a typical plateau continental climate dominated by the southeast monsoons from May to September and high-pressure systems from Siberia in winter. The climate is characterized by a cold winter and short, cool summer. The mean annual air temperature is $-1.7^{\circ} \mathrm{C}$. The maximum monthly mean air temperature is $10^{\circ} \mathrm{C}$ in July and the minimum is $-15^{\circ} \mathrm{C}$ in January. Mean temperature and rainfall from $1^{\text {st }}$ May to the $20^{\text {th }}$ September in 2006 and 2007 (growing season and data collection period) were 8.4 and $8.5^{\circ} \mathrm{C}$, and 449 and $398 \mathrm{~mm}$, respectively (Luo et al., 2010). The plant community at the experimental site is dominated by perennial graminoids such as Kobresia humilis, Festuca ovina, Elymus nutans, Poa pratensis, and Carex scabrirostris (Wang et al., 2012). The canopy height of the vegetation in August was about 15-20 cm (Luo et al., 2009). More than $95 \%$ of belowground plant biomass can be found in the upper $20 \mathrm{~cm}$ and fine root biomass is higher at $10-20 \mathrm{~cm}$ soil depth than at $0-10 \mathrm{~cm}$ depth $(\mathrm{Wu}$ et al., 2011).

\section{Controlled warming-grazing experiment}

In May 2006, we set up a warming $\times$ grazing experiment with four replicates for each treatment combination, i.e., no warming no grazing (NWNG), no warming with grazing (NWG), warming with no grazing (WNG), and warming with grazing (WG). In total, 16 circular plots ( $3 \mathrm{~m}$ diameter) were used in a complete randomized block design. For the warming treatments we used an infrared heating system, hereafter 
called free-air temperature enhancement (FATE) system, as described by Kimball et al. (2008). In summer (April-October), the set point differences between the heated and control plots were $1.2^{\circ} \mathrm{C}$ during daytime and $1.7^{\circ} \mathrm{C}$ at night, which falls within the range of the predicted temperature increase for this century for this region $\left(1.5-5^{\circ} \mathrm{C}\right.$; Wang at al., 2012). In winter, the power output of the heaters were manually set at $1500 \mathrm{~W}$ per plot.

One adult Tibetan domestic sheep (Ovis aries) was fenced in the grazing plots on the morning of $17^{\text {th }}$ August 2006 for two hours. Similarly, two adult Tibetan sheep were fenced for one hour in the grazing plots in the mornings of $12^{\text {th }}$ July and $3^{\text {rd }}$ August in 2007. The height of the vegetation was measured at 50 points within the plots before and after grazing, and the sheep were removed from the grazing plots when the canopy height was reduced to approximately half of the initial height, which generally corresponded to a moderate stocking rate in the region (Luo et al., 2009; Wang et al., 2012).

\section{Soil temperature and soil moisture}

Soil temperature was measured automatically using type-K thermocouples (Campbell Scientific, Logan, UT, USA) at depths of 5,10 and $20 \mathrm{~cm}$. All the thermocouples were connected to a CR1000 datalogger. Soil temperature was measured every minute, and 15 min averages were stored. Soil moisture was manually measured at depths of 10 , 20, 30 and $40 \mathrm{~cm}$ at 08:00 h, 14:00 h, and 20:00 h daily. All data were collected from May $26^{\text {th }}$ to September $20^{\text {th }} 2006$ and from May $1^{\text {st }}$ to September $20^{\text {th }}$ in 2007 (Luo et 
al., 2009).

Litter, aboveground and belowground plant biomass, $\mathbf{N}$ concentration, and

In August of 2006 and 2007, litter and above- and below-ground plant biomass were collected from two $10 \times 10 \mathrm{~cm}$ quadrats in each of the plots. Plant samples were dried at $80^{\circ} \mathrm{C}$ for $48 \mathrm{~h}$ after which their dry weight was measured. Subsequently, sub-samples of roots and shoots were ground and used to determine concentrations of $\mathrm{N}$ using a Kjeldahl digestion method with an Alpkem autoanalyzer (Kjektec System1026 Distilling Unit, Sweden). Above- and below-ground plant N uptake was calculated multiplying biomass by the $\mathrm{N}$ concentration in the respective plant tissue (Finzi et al., 2007).

\section{Soil pore water sampling and analysis}

Soil pore water was collected at 2-4 week intervals during two consecutive growing seasons (10 and 24 June, 10 and 24 July, 16 August in 2006; and 27 May, 10 and 24 July, 24 August in 2007) within $24 \mathrm{~h}$ after rainfall using porous-cup ceramic zero-tension samplers, which were made by the Institute of Geographical Sciences and Natural Resources Research of the Chinese Academy of Sciences in Beijing. These samplers were placed at soil depths of 10, 20, 30 and $40 \mathrm{~cm}$ in each plot on 24 May in 2006. Soil solution samples were collected from each plot with a vacuum pump, placed in amber bottles, and stored in a refrigerator at $4{ }^{\circ} \mathrm{C}$ until further analysis. 
191 All samples were filtered through $0.7 \mu \mathrm{m}$ pore diameter membranes prior to analysis

192 (Glass Microfibre Filters, GF/F, Whatman, Schleicher and Schuell, England). Total

193 dissolved N (TDN), dissolved organic C (DOC) and DON, concentrations in the soil

194 solution were measured using a Shimadzu 5000 TOC/TN analyzer (Kyoto, Japan).

195 Ammonium-N in the soil solutions was determined colorimetrically by the

196 salicylate-nitroprusside method of Mulvaney (1996) on a plate reader (Scientific

197 International, New Delhi, India). Nitrate-N was determined colorimetrically using the

198 N-1-napthylethylenediame method of Miranda et al. (2001) using the same plate

199 reader. DON was calculated as the difference between the TDN reading and the amount of dissolved inorganic $\mathrm{N}\left(\mathrm{DIN} ; \mathrm{NH}_{4}{ }^{+}+\mathrm{NO}_{3}{ }^{-}\right)$present.

\section{Statistical analysis}

203 Treatment effects on soil TDN, DON concentration, and $\mathrm{NH}_{4}{ }^{+}-\mathrm{N}$ and $\mathrm{NO}_{3}{ }^{-}-\mathrm{N}$ concentration were tested using repeated-measures analyses of variance (ANOVA), 205 with warming, grazing and their interaction as the main factors (between-subject 206 factors) and with sample date and soil depth as within-subject factors. 207 Multi-comparisons of least standard difference (LSD) were conducted for all measured variables within each sampling date and each soil depth using a one-way

209 ANOVA. Because all plots were free from grazing until 17 August 2006, the data

210 before that date were analyzed separately. For all ANOVAs, the assumption of 211 normality was checked with Kolmogorov-Smirnov tests and the assumption of 212 homogeneity of variances was checked using Levene's tests. If the assumptions were 
not met, data were log-transformed prior to analysis. Statistical analyses were performed using SPSS, version 15.0 (SPSS Inc., Chicago, IL, USA). Regression analyses were used to test the relationships between DON concentration across $0-40 \mathrm{~cm}$ soil depth and at individual soil depths $(0-10 \mathrm{~cm}, 10-20$ $\mathrm{cm}, 20-30 \mathrm{~cm}$ and $30-40 \mathrm{~cm}$ ) and the corresponding soil temperature, soil moisture, soil $\mathrm{pH}$, soil $\mathrm{NH}_{4}{ }^{+}$and $\mathrm{NO}_{3}{ }^{-}$concentration, soil total dissolved $\mathrm{C}$ concentration and DOC concentration. Regressions were run separately for 2006 and for 2007 as well as across the 2006-2007 period. Regressions were run across treatments, but also within individual treatments. Simple correlation analyses were also performed between above- or below-ground plant $\mathrm{N}$ uptake and the corresponding seasonal mean soil DON and soil DIN $\left(\mathrm{NH}_{4}{ }^{+}-\mathrm{N}\right.$ and soil $\left.\mathrm{NO}_{3}{ }^{-}-\mathrm{N}\right)$ concentrations. To test the relative importance of biotic and abiotic factors in determining DON concentration, we ran stepwise multiple regressions between mean seasonal DON concentration at different soil depths and various biotic factors (i.e., above- and belowground plant biomass, above- and below-ground plant $\mathrm{N}$ uptake, dead standing plant biomass, and concentrations of chemical components of dead standing biomass ( $\mathrm{C}$ content, $\mathrm{N}$ content, cellulose content, hemicellulose content, lignin content and lignin-N content) and abiotic factors (i.e., soil chemical factors such as, total $\mathrm{C}, \mathrm{DOC}, \mathrm{pH}, \mathrm{NH}_{4}{ }^{+}-\mathrm{N}$ and $\mathrm{NO}_{3}{ }^{-}-\mathrm{N}$ and soil physical factors such as, temperature and moisture).

\section{Results}

\section{Effects of warming and grazing on soil moisture and temperature}


Both warming and grazing did not significantly affect soil moisture content at any of the 5 measured soil depths in either 2006 or 2007 (Luo et al., 2009). Warming increased soil temperature in the $0-10 \mathrm{~cm}$ soil layer both before and after grazing (Table S1; Supplementary on-line information). In addition, sheep grazing with or without external warming also resulted in a significant rise in soil temperature (Table S1).

\section{Effects of warming and grazing on dissolved nitrogen components and}

\section{DOC/DON}

Warming significantly decreased total dissolved soil $\mathrm{N}(\mathrm{TDN})$ in the $0-40 \mathrm{~cm}$ soil layer by approximately $6 \%$ and $17 \%$ before and after the grazing treatments started in 2006, respectively (Table 1; Fig. 2), however, there was no effect of warming on TDN in 2007 (Table 1). For TDN, there was a significant warming $\times$ soil depth interaction before grazing started in 2006; warming decreased TDN by $16 \%, 18 \%$ and $7 \%$ in the 0-10 cm, 10-20 cm and 20-30 cm soil layers, respectively (Fig. 2).

DON constituted a large component of the soluble $\mathrm{N}$ in soil, accounting for approximately $80-90 \%$ of the TDN. Warming significantly decreased DON concentrations before and after the grazing treatments in 2006 by $16 \%$ and $10 \%$ in the 10-20 and 20-30 cm soil depths respectively, and in 2007 by $36 \%$ in the $10-20 \mathrm{~cm}$ soil layer in 2007 (Table 1). After the grazing treatment started, there was a significant warming $\times$ grazing $\times$ soil depth $\times$ sampling date interaction in 2006 and in 2007 (Table 1), indicating that the effects of warming and grazing on DON were dependent 
on soil depth and sampling date (Fig. 2, Fig. 3, see also on-line supplementary information).

$\mathrm{NH}_{4}{ }^{+}-\mathrm{N}$ and $\mathrm{NO}_{3}{ }^{-}-\mathrm{N}$ constituted rather small components of the total pool of soluble soil $\mathrm{N}$, accounting for approximately $10-15 \%$ or $<10 \%$ of the concentration of TDN, respectively. There was a significant warming $\times$ date interaction on $\mathrm{NH}_{4}{ }^{+}-\mathrm{N}$ concentrations before and after the grazing treatment started in 2006 (Table 1), with both positive and negative effects seen depending on season and year (Fig. 2). Warming decreased $\mathrm{NO}_{3}{ }^{-} \mathrm{N}$ concentration by $>50 \%$ after the grazing treatments started in 2006 and in 2007 (Table 1) (Fig. 2). However, effects of warming and grazing on $\mathrm{NO}_{3}{ }^{-}-\mathrm{N}$ concentration were strongly dependent on soil depth and sampling date.

Warming significantly increased the DOC-to-DON ratio in the 0-10 and 10-20 $\mathrm{cm}$ soil layers but induced a decrease in the $30-40 \mathrm{~cm}$ soil layer prior to the onset of grazing (see on-line supplementary information Table S2). After grazing, warming a significant increase in the DOC-to-DON ratio was only seen in the $10-20 \mathrm{~cm}$ soil layer (see on-line supplementary information Table S3).

\section{Effects of warming and grazing on litter quality, plant biomass and $\mathrm{N}$ uptake}

In both years, warming increased the amount of dead standing plant biomass, whereas grazing significantly decreased the amount of dead standing plant biomass. Warming and grazing also significantly increased the $\mathrm{N}$ concentration in dead standing biomass (see on-line supplementary information Table S4).

Warming significantly increased below-ground plant biomass in $2006(\mathrm{~F}=20.54$; $P<0.001$ ); in the warmed plots, root biomass was on average $25 \%$ higher than in the 
control plots in 2006. Grazing and warming $\times$ grazing did not significantly affect

282

283 below-ground plant biomass in 2006 ( $\mathrm{F}=0.95,2.60 ; P=0.33,0.11$, respectively). There was a significant warming $\times$ grazing interaction effect on below-ground plant biomass in $2007(\mathrm{~F}=11.31 ; P<0.001)$. Warming significantly increased above-ground plant biomass production in 2006 and 2007 and there was a weak warming $\times$ grazing effect on plant above-ground biomass in 2007; grazing did not affect plant above-ground biomass in 2006, but significantly reduced plant biomass in 2007 (Wang et al., 2012).

Warming significantly increased $\mathrm{N}$ uptake in above-ground plant biomass by approximately $18 \%$ in 2006 and $24 \%$ in 2007 . Warming also increased $\mathrm{N}$ uptake in below-ground plant biomass (upper $20 \mathrm{~cm}$ soil depth), up to $25 \%$ in 2006 and $35 \%$ in 2007 (Table 2; Fig. 4). Grazing did not affect plant above- and below-ground N uptake in 2006, but grazing significantly decreased $\mathrm{N}$ uptake in above-ground plant biomass by up to $20 \%$ and below-ground plant $\mathrm{N}$ uptake (upper $20 \mathrm{~cm}$ soil depth) by up to $40 \%$ in 2007 (Table 2; Fig. 4). There was a warming $\times$ grazing effect on below-ground plant $\mathrm{N}$ uptake at 0-10 cm soil depth in 2007 (Table 2).

\section{Relationships between DON concentration and abiotic and biotic variables}

There was a significant positive correlation between DON concentration at $10-20 \mathrm{~cm}$ soil depth and soil temperature in 2006 (Table 3). There were negative correlations between DON and soil moisture, $\mathrm{NH}_{4}{ }^{+}-\mathrm{N}$, and $\mathrm{pH}$ in 2006 and 2007 at $0-40 \mathrm{~cm}$ soil depth, and between daily DON and $\mathrm{NO}_{3}{ }^{-}-\mathrm{N}$ only for the no warming and no grazing treatments in 2007 (Table 3). Stepwise regressions showed that the mean seasonal DON concentration at different soil depths was significantly affected by biotic factors. 
For example, at 10-20 cm soil depth, a negative correlation was found between DON and below-ground plant $\mathrm{N}$ uptake and plant $\mathrm{N}$ uptake explained approximately $42 \%$ of the variation in $\mathrm{DON}(\mathrm{F}=9.97, P=0.007)$. In the $30-40 \mathrm{~cm}$ soil layer, a positive correlation was found between DON and plant $\mathrm{N}$ uptake, which explained approximately $36 \%$ of the variation in $\mathrm{DON}(\mathrm{F}=8.04, P=0.013)$.

At 0-20 cm soil depth in 2006 and 2007, above- and below-ground plant $\mathrm{N}$ uptake was negatively correlated with mean seasonal DON concentrations. No significant correlations were found between above- and below-ground plant $\mathrm{N}$ uptake and dissolved inorganic $\mathrm{N}$ (including $\mathrm{NH}_{4}{ }^{+}-\mathrm{N}, \mathrm{NO}_{3}{ }^{-}-\mathrm{N}$ ) (Fig. 5).

\section{Discussion}

Dissolved organic nitrogen $(\mathrm{DON})$ represents a significant pool of soluble $\mathrm{N}$ in many ecosystems and plays an important role in the $\mathrm{N}$ cycling of terrestrial ecosystems (Jones et al., 2004; Bai et al., 2013; Ueda et al., 2013). Our results showed that DON accounted for more than $80 \%$ of the total dissolved soil N (TDN) in Tibetan alpine meadows which is consistent with the hypothesis that DON is the quantitatively dominant pool of high elevation, N-limiting ecosystems (Schimel and Bennett, 2004;

Christou et al., 2005; Kranabetter et al., 2007; Näsholm et al., 2009). For instance, Farrell et al. (2011) noted that DON is relatively more abundant than DIN in higher altitude N-limiting grasslands than in productive lowland grasslands. Next we consider our findings in more detail, in the context of soil DON concentrations and their dynamics under warming and grazing.

Our results supported our hypothesis that warming decreased DON, particularly at 
10-20 cm soil depths. Among the potential sources of DON, many studies have argued that DON in soil mainly originates from the decomposition of plant litter (Kalbitz et al., 2000; Chapman et al., 2001; Haynes 2005) or root exudates (Jones et al., 1994; Haynes 2005; Jones et al., 2005; Jones et al., 2008; Strickland et al., 2012) (Fig.1). Our observations at the site have shown that warming increased plant aboveand below-ground biomass, improved the quality of leaf litter, and accelerated litter decomposition (Luo et al., 2010). This suggests that warming may enhance the production rates of DON in soil. However, our results showed that warming significantly decreased DON, particularly at 10-20 cm soil depths (where typically most of the fine roots were found; Kuzyakov and $\mathrm{Xu}$ 2013; Wu et al., 2011). In general, there are three dominant fates of soil DON in soil solution (Fig. 1): Firstly, DON can be sorbed to the solid phase, however, this is not likely to be affected by warming. Secondly, DON can be immobilized by the soil microbial community to support their nitrogen and/or carbon requirements (Jones et al., 2004, Jones et al., 2005) and thirdly it can be both converted to $\mathrm{NH}_{4}{ }^{+}$by the action of both intra- and extra-cellular enzymes (Bardgett et al., 2003; Jones et al., 2004; Bai et al., 2013). Warming significantly increased soil microbial biomass- $\mathrm{C}$ and $-\mathrm{N}$ in this experiment in 2009 (Rui et al., 2010) suggesting that greater rates of DON immobilization and mineralization. This is supported by previous studies showing that experimental warming enhances the decomposition of soil organic $\mathrm{N}$ and mineralization via increased microbial activity (e.g., Bardgett et al., 2008; Luo et al., 2010). Our results showed that warming decreased DON in both 2006 and 2007, with the difference 
evident early in the growing season and at the end of the growing season (Fig. 2). This decrease in DON is temporally consistent with increased soil temperatures, microbial activity and soil respiration (by ca. 10\%) occurring at the same time (Lin et al., 2011) supporting the view that loss of DON was due to accelerated DON decomposition. However, this hypothesis is not consistent with Wang et al. (2012) who found that warming did not significantly affect soil net $\mathrm{N}$ mineralization at the same site. It DIN uptake and it is possible that warming increased gross $\mathrm{N}$ mineralization.

should be noted, however, that the measurement of net $\mathrm{N}$ mineralization ignored plant

Plants roots and their associated mycorrhizas can directly take up low molecular weight DON to support plant growth (Jones et al., 2004; Jones et al., 2005; Xu et al., 2006; Jämtgård et al., 2008; Xu et al., 2011). This DON loss pathway within our experiment is potentially supported by a significant negative correlation between plant $\mathrm{N}$ uptake and soil DON (Fig. 5). Moreover, plant $\mathrm{N}$ uptake explained approximately $42 \%$ of variation in DON concentration at $10-20 \mathrm{~cm}$ soil depth. In 2007 , warming decreased DON at 10-20 $\mathrm{cm}$ soil depth by $8.34 \mathrm{~g} \mathrm{~m}^{-2}$, while plant $\mathrm{N}$ uptake increased by $11.72 \mathrm{~g} \mathrm{~m}^{-2}$. However, $\mathrm{Xu}$ et al. (2006) suggests that plants take up a maximum of $30 \%$ of $\mathrm{N}$ as organic $\mathrm{N}$ (Xu et al., 2006, 2011) indicating that soil organic $\mathrm{N}$ would only decrease by $3.51 \mathrm{~g} \mathrm{~m}^{-2} \mathrm{y}^{-1}$. Further, experiments using dual-labeled ${ }^{13} \mathrm{C}-{ }^{15} \mathrm{~N}$-glycine showed that the warming decreased plant capture of amino acid-N from soil (Ma et al., 2015 under review). The results of Xu et al. (2006, 2011) and Ma et al. (2015), however, must be placed against the huge uncertainty inherent in measuring and interpreting the uptake of ${ }^{15} \mathrm{~N}$-DON by plants (Jones et al., 2005). In 
addition, recent studies in $\mathrm{N}$-limiting environments suggest that plants compete at a higher level in the $\mathrm{N}$ breakdown pathway by taking up small peptides from soil, thereby by-passing the need to take up amino acids, $\mathrm{NH}_{4}{ }^{+}$and $\mathrm{NO}_{3}^{-}$(Hill et al., 2011a,b, 2012). Further work is therefore required to determine the chemical nature of DON in these soils and to determine their relative availability to both plants and microorganisms.

DON could also potentially leave this ecosystem via leaching (Hu et al., 2010). In our experiment we conclude that leaching is probably of minor importance due to the lack of observed differences in soil moisture content and the inherently low rates of water mobility (Zhu et al., 2011).

Previous studies at the site showed that warming increased soil temperature by 0.5 to $1.5{ }^{\circ} \mathrm{C}$ across all soil depths both in 2006 and in 2007 , while grazing only increased soil temperature in 2007. In this study, we found that there was only a weak positive correlation between soil temperature with DON $\left(r^{2}=0.08\right)$ and a weak negative correlation between soil moisture and DON concentration $\left(r^{2}=0.05\right)$. This indicates that abiotic factors probably only play a minor role in directly modulating DON concentrations in Tibet alpine meadow ecosystems. The poor relationships of these abiotic variables with soil DON also highlights the potential influence of biotic factors in regulating soil DON concentrations (Lü et al., 2014).

Our results confirmed our hypothesis that grazing increased soil DON, opposite to the effect of warming. Overall, grazing increased below-ground plant biomass production (Hu et al., 2010; Wang et al., 2012) and increased rates of litter 
decomposition (Luo et al., 2010), both of which are known to positively influence rates of DON production. Grazing could also influence soil DON by: (1) increasing soil temperature, changing soil moisture status (Asner et al., 2004; Christou et al., 2005) or by inducing alterations in soil structure and hydrological flow pathways (via sheep trampling). This can produce a complex range of both negative and positive feedbacks on rates of DON production and consumption (Holst et al., 2007; Wu et al., 2011; Houst et al., 2007; Kauffman et al., 2004); (2) Grazing can reduce rates of litterfall and can decrease litter quality (Luo et al., 2011), which can decrease $\mathrm{N}$ both in the plant (Fig. 4) and microbial N pools (Rui et al., 2011). Our results showed that grazing decreased above- and below-ground plant total $\mathrm{N}$ uptake by about $25 \%$ which could have further contributed to the loss of DON through plant uptake; and (3) Our results show that grazing strongly increases soil $\mathrm{NO}_{3}{ }^{-}$concentrations. This result is consistent with the founding of Rui et al. (2011) in 2009 at the same site and those of Wu et al. (2011) in the Inner Mongolia steppes. The increase in $\mathrm{NO}_{3}{ }^{-}$concentrations under grazing could be explained by the addition of sheep excreta especially at the soil surface (Fig. 3).

\section{Conclusions}

Our results showed that warming decreased soil DON concentrations and that conversely, grazing increased soil DON concentrations. We suggest that a warming-induced reduction in DON can be ascribed to accelerated rates of plant and microbial uptake of DON rather than changes in DON production rate or leaching 
losses. Further work is therefore required to (1) characterize and quantify the chemical nature of DON, (2) determine the biological fate of DON under warming and grazing treatment, and (3) develop modeling tools to enable prediction of anthropogenically mediated changes in environment on DON pool or fluxes.

\section{Acknowledgements}

This work was supported by funding from the Strategic Priority Research Program (B) of the Chinese Academy of Sciences (XDB03030403), National Basic Research Program (2013CB956000) and National Science Foundation of China (41301600, 41230750). Support was also provided by the UK Natural Environmental Research Council. We thank Zhichun Lan and Wang Yang for help with the figures.

\section{References}

Ajwa, H.A., Dell C, J., Rice, C.W., 1999. Changes in enzyme activities and microbial biomass of tallgrass prairie soil as related to burning and nitrogen fertilization. Soil Biol. Biochem. 31, 769-777.

Asner, G.P., Elmore, A.J., Olander, L.P., Martin, R.E., Harris, A.T., 2004. Grazing systems, ecosystem responses, and global change. Ann. Rev. Environ. Res. 29, 261-299.

Averill, C., Finzi, A.C., 2011. Icreasing plant use of organic nitrogen with elevation is reflected in nitrogen uptake rates and ecosystem delta N-15. Ecology 92, 883-891.

Bai, E., Li, S.L., Xu, W.H., Li, W., Dai, W.W., Jiang, P., 2013. A meta-analysis of 

Phytol. 199, 441-451.

440 Bardgett, R.D., Streeter, T.C., Bol, R., 2003. Soil microbes compete effectively with plants for organic-nitrogen inputs to temperate grasslands. Ecology 84, 1277-1287.

Bardgett, R.D., Freeman, C., Ostle, N.J., 2008. Microbial contributions to climate change through carbon cycle feedbacks. Isme J. 2, 805-814.

Birgander, J., Reischke, S., Jones, D.L., Rousk, J., 2013. Temperature adaptation of bacterial growth and C-14-glucose mineralisation in a laboratory study. Soil Biol. Biochem. 65, 294-303.

Bowles, T.M., Acosta-Martínez, V., Calderón, F., Jackson, L.E., 2014. Soil enzyme activities, microbial communities, and carbon and nitrogen availability in organic agroecosystems across an intensively-managed agricultural landscape. Soil Biol. Biochem. 68, 252-262.

Butler, S.M., Melillo, J.M., Johnson, J., Mohan, J., Steudler, P.A., Lux, H., Burrows, E., Smith, R., Vario, C., Scott, L., 2012. Soil warming alters nitrogen cycling in a New England forest: implications for ecosystem function and structure. Oecologia 168, 819-828.

Chapman, P., Williams, B., Hawkins, A., 2001. Influence of temperature and vegetation cover on soluble inorganic and organic nitrogen in a spodosol. Soil Biol. Biochem. 33, 1113-1121.

Chapuis-Lard, L., Wrage, N., Metay, A., Chotte, J.L., Bernoux, M., 2007. Soils, a sink for $\mathrm{N}_{2} \mathrm{O}$ ? A review. Glob. Chang. Biol. 13, 1-17. 
Christou, M., Avramides, E.J., Jones, D.L., 2006. Dissolved organic nitrogen dynamics in a Mediterranean vineyard soil. Soil Biol. Biochem. 38, 2265-2277.

Christou, M., Avramides, E.J., Roberts, J.P., Jones, D.L., 2005. Dissolved organic nitrogen in contrasting agricultural ecosystems. Soil Biol. Biochem. 37, 1560-1563.

Elser, J.J., Bracken, M.E., Cleland, E.E., Gruner, D.S., Harpole, W.S., Hillebrand, H., Ngai, J.T., Seabloom, E.W., Shurin, J.B., Smith, J.E., 2007. Global analysis of nitrogen and phosphorus limitation of primary producers in freshwater, marine and terrestrial ecosystems. Ecol. Lett. 10, 1135-1142.

Farrell, M., Hill, P.W., Farrar, J., Bardgett, R.D., Jones, D.L., 2011. Seasonal variation in soluble soil carbon and nitrogen across a grassland productivity gradient. Soil Biol. Biochem. 43, 835-844.

Farrell, M., Hill., P.W., Wanniarachchi, S.D., Farrar, J., Bardgett, R.D., Jones., D.L., 2011. Rapid peptide metabolism: A major component of soil nitrogen cycling? Glob. Biogeochem. Cycles 25, 11.

Farrell, M., Hill, P.W., Farrar, J., Deluca, T.H., Roberts, P., Kielland, K., Dahlgren, R., Murphy, D.V., Hobbs, P.J., Bardgett, R.D., Jones, D.L., 2013. Oligopeptides represent a preferred source of organic $\mathrm{N}$ uptake: A global phenomenon? Ecosystems 16, 133-145.

Finzi, A.C., Norby, R.J., Calfapietra, C., Gallet-Budynek, A., Gielen, B., Holmes, W.E., Hoosbeek, M.R., Iversen, C.M., Jackson, R.B., Kubiske, M.E., Ledford, J., Liberloo, M., Oren, R., Polle, A., Pritchard, S., Zak, D.R., Schlesinger, W.H., 

efficiency support higher rates of temperate forest productivity under elevated $\mathrm{CO}_{2}$. Proc. Natl. Acad. Sci. USA 104, 14014-14019.

Fu, G., Shen, Z.X., Zhang, X.Z., Zhou, Y.T., 2012. Response of soil microbial biomass to short-term experimental warming in alpine meadow on the Tibetan Plateau. Appl. Soil Ecol. 61, 158-160.

Frank, D.A., Groffman, P.M., Evans, R.D., Tracy, B.F., 2000 Ungulate stimulation of nitrogen cycling and retention in Yellowstone Park grasslands. Oecologia

Giorgi, F., Hewitson, B., Christensen, J., 2001. Climate change 2001:Regional climate information-evaluation and projections. In:Houghton. J.T., Griggs, D.J., Noguer, M., Van der linden, O.J., Dai, X., Maskell, K., Johnson, C.A., (eds) Climate change 2001: TheScientific Basis. Contribution of Working Group I to the Third Assessment Report of the Intergovernmental Panel on ClimateChange. Cambridge University Press, Cambridge 584-636

Groffmann, P.M., Zak, D.R., Christensen, S., Mosie, A., Tiedje, J.M., 1993. Early spring nitrogen dynamics in a temperate forest landscape. Ecology 1579-1585.

Harrison, K.A., Bardgett, R.D., 2004. Browsing by red deer negatively impacts on soil nitrogen availability in regenerating native forest. Soil Biol. Biochem. 36, 115-126. Haynes, R., 2005. Labile organic matter fractions as central components of the quality of agricultural soils: an overview. Adv. Agron. 85. 221-268.

Hill. P.W., Farrell, P., Roberts., Farrar, J., Grant, H., Newsham, K., Hopkins, D.W., 
amino acids and their peptides by Antarctic soil microorganisms. Soil Biol. Biochem. 43. 2410-2416.

Hill, P.W., Quilliam, R.S., DeLuca, T.H., Farrar, J., Farrell, M., Roberts, P., Newsham, K.K., Hopkins, D.W., Bardgett, R.D., Jones, D.L., 2011b. Acquisition and assimilation of nitrogen as peptide-bound and D-enantiomers of amino acids by wheat. Plos One 6, 4 .

Hill, P.W., Farrell, M., Jones, D.L., 2012. Bigger may be better in soil N cycling: Does rapid acquisition of small L-peptides by soil microbes dominate fluxes of protein-derived N in soil? Soil Biol. Biochem. 428, 106-111.

Holst, J., Liu, C.Y., Bruggemann, N., Butterbach-Bahl, K., Zheng, X.H., Wang, Y.S., 623-634.

Hu. Y., Chang, X., Lin, X., Wang, Y., Wang, S., Duan, J., Zhang, Z., Yang, X., Luo,

Huang, W.Z., Schoenau, J.J., 1998. Fluxes of water-soluble nitrogen and phosphorus in the forest floor and surface mineral soil of a boreal aspen stand. Geoderma 81,

Jämtgård, S., Näsholm, T., Huss-Danell, K., 2008. Characteristics of amino acid uptake in barley. Plant Soil 302, 221-231.

Jämtgard, S., Näsholm, T., Huss-Danell, K., 2010. Nitrogen compounds in soil 

represents a major bottleneck in nitrogen cycling in grassland soils. Soil Biol. Biochem. 41, 2272-2282.

Jones, D., Edwards, A., Donachie, K., Darrah, P., 1994. Role of proteinaceous amino acids released in root exudates in nutrient acquisition from the rhizosphere. Plant Soil 158,183-192.

Jones, D.L., Healey, J.R., Willett, V.B., Farrar, J.F., Hodge, A., 2005. Dissolved organic nitrogen uptake by plants - an important $\mathrm{N}$ uptake pathway? Soil Biol. Biochem. 37, 413-423.

Jones, D.L., Hughes, L.T., Murphy, D.V., Healey, J.R., 2008. Dissolved organic carbon and nitrogen dynamics in temperate coniferous forest plantations. Eur. J. Soil. Sci. 59, 1038-1048.

Jones, D.L., Kielland, K., Sinclair, F.L., Dahlgren, R.A., Newsham, K.K., Farrar, J.F., Murphy, D.V., 2009. Soil organic nitrogen mineralization across a global latitudinal gradient. Glob. Biogeochem. Cy. 23, 1016-1021.

Kalbitz, K., Glaser, B., Bol, R., 2004. Clear-cutting of a Norway spruce stand: implications for controls on the dynamics of dissolved organic matter in the forest floor. Eur. J. Soil. Sci. 55, 401-413. 
Kalbitz, K., Solinger, S., Park, J.H., Michalzik, B., Matzner, E., 2000. Controls on the dynamics of dissolved organic matter in soils: a review. Soil Sci. 165, 277-304.

Kauffman, J.B., Thorpe, A.S., Brookshire, E.N.J., 2004. Livestock exclusion and belowground ecosystem responses in riparian meadows of Eastern Oregon. Ecol. Appl. 14, 1671-1679.

Kielland, K., 1994. Amino acid absorption by arctic plants: implications for plant nutrition and nitrogen cycling. Ecology 75, 2373-2383.

Kimball, B.A., Conley, M.M., Wang, S., Lin, X., Luo, C., Morgan, J., Smith, D., 2008. Infrared heater arrays for warming ecosystem field plots. Glob. Chan. Biol. 14, 309-320.

Kögel-Knaber, I., 2006. Chemical structure of organic N and organic P in soils. In: Nannipieri, P., Smalla, K. (Eds.), Nucleic Acids and Proteins in Soils. SpringereVerlag, Berlin, pp. 23-48.

Kranabetter, J.M., Dawson, C.R., Dunn, D.E., 2007. Indices of dissolved organic nitrogen, ammonium and nitrate across productivity gradients of boreal forests. Soil Biol. Biochem. 39, 3147-3158.

Le, R.X., Bardy, M., Loiseau, P., Louault, F., 2003. Stimulation of soil nitrification and denitrification by grazing in grasslands: do changes in plant species composition matter? Oecologia 137, 417-425.

Lebauer, D.S., Treseder, K.K., 2008. Nitrogen limitation of net primary productivity in terrestrial ecosystems is globally distributed. Ecology 89, 371-379.

Lü, X.T., Dijkstra, F.A., Kong, D.L., Wang, Z.W., Han, X.G., 2014. Plant nitrogen 
uptake drives responses of productivity to nitrogen and water addition in a grassland. Sci. Rep. 4, 4817.

Lin, X.W., Zhang, Z.H., Wang, S.P., Hu, Y.G., Xu, G.P., Luo, C.Y., Chang, X.F., Duan, J.C., Lin, Q.Y., Xu, B.Y., Wang, Y.F., Zhao, X.Q., Xie, Z.B., 2011. Response of ecosystem respiration to warming and grazing during the growing seasons in the alpine meadow on the Tibetan plateau. Agricul, For. Meteor. 151, $792-802$.

Luo, C., Xu, G., Chao, Z., Wang, S., Lin, X., Hu, Y., Zhang, Z., Duan, J., Chang, X., $\mathrm{Su}$, A., 2010. Effect of warming and grazing on litter mass loss and temperature sensitivity of litter and dung mass loss on the Tibetan plateau. Glob. Change Biol. $16,1606-1617$.

Luo, C., Xu, G., Wang, Y., Wang, S., Lin, X., Hu, Y., Zhang, Z., Chang, X., Duan, J., $\mathrm{Su}$, A., 2009. Effects of grazing and experimental warming on DOC concentrations in the soil solution on the Qinghai-Tibet plateau. Soil Biol. Biochem. 41, 2493-2500.

Näsholm, T., Ekblad, A., Nordin, A., Giesler, R., Hogberg, M., Hogberg, P., 1998. Boreal forest plants take up organic nitrogen. Nature 392, 914-916.

Näsholm, T., Kielland, K., Ganeteg, U., 2009. Uptake of organic nitrogen by plants. New Phytol. 182, 31-48.

Nordin, A., Schmidt, I.K., Shaver, G.R., 2004. Nitrogen uptake by arctic soil microbes and plants in relation to soil nitrogen supply. Ecology 85, 955-962.

Persson, J., Högberg, P., Ekblad, A., Högberg, M.N., Nordgren, A., Näsholm, T., 
2003. Nitrogen acquisition from inorganic and organic sources by boreal forest plants in the field. Oecologia 137, 252-257.

594 Roberts, P., Jones, D.L., 2012. Microbial and plant uptake of free amino sugars in 595 grassland soils. Soil Biol. Biochem. 49, 139-149.

596 Rui, Y.C., Wang, S.P., Xu, Z.H., Wang, Y.F., Chen, C.R., Zhou, X.Q., Kang, X.M., 597 Lu, S.B., Hu, Y.G., Lin, Q.Y., Luo, C.Y., 2011. Warming and grazing affect soil 598 labile carbon and nitrogen pools differently in an alpine meadow of the 599 Qinghai-Tibet Plateau in China. J Soils Sed. 11, 903-914.

600 Schimel, J.P., Bennett, J., 2004. Nitrogen mineralization: challenges of a changing $601 \quad$ paradigm. Ecology 85, 591-602.

602 Shan, S., Coleman, M., Kimsey, M., 2014. Soil Soluble Nitrogen Availability across 603 an Elevation Gradient in a Cold-Temperate Forest Ecosystem. Soil Sci. Soc. Am. J. $604 \quad 78$, S217-S224.

605 Stark, S., Wardle, D.A., Ohtonen, R., Helle, T., Yeates, G.W., 2000. The effect of 606 reindeer grazing on decomposition, mineralization and soil biota in a dry 607 oligotrophic Scots pine forest. Oikos 90, 301-310.

608 Strickland, M.S., Wickings, K., Bradford, M.A., 2012. The fate of glucose, a low 609 molecular weight compound of root exudates, in the belowground foodweb of 610 forests and pastures. Soil Biol. Biochem. 49, 23-29.

611 Thompson, L.G., Yao, T., Mosley-Thompson, E., Davis, M.E., Henderson, K.A., Lin, 612 P.N., 2000. A high-resolution millennial record of the South Asian Monsoon from 613 Himalayan ice cores. Science 289, 1916-1919. 
614

615

616

617

618

619

620

621

622

623

624

625

626

627

628

629

630

631

632

633

634

635

Ueda, M.U., Muller, O., Nakamura, M., Nakaji, T., Hiura, T., 2013. Soil warming decreases inorganic and dissolved organic nitrogen pools by preventing the soil from freezing in a cool temperate forest. Soil Biol. Biochem. 61, 105-108.

Vitousek, P,M, Howarth, R.W., 1991. Nitrogen limitation on land and in the sea: how can it occur? Biogeochem. 13, 87-115.

Wang, S., Duan, J., Xu, G., Wang, Y., Zhang, Z., Rui, Y., Luo, C., Xu, B., Zhu, X., Chang, X., 2012, Effects of warming and grazing on soil $\mathrm{N}$ availability, species composition, and ANPP in an alpine meadow. Ecology 93, 2365-2376.

Wang, B.L., French, H.M., 1994. Climate controls and high-altitude permafrost, Qinghai-Xizang (Tibet) Plateau, China. Permafrost Periglac. 5, 87-100.

Warren, C.R., 2013. Quaternary ammonium compounds can be abundant in some soils and are taken up as intact molecules by plants. New Phytol. 198, 476-485.

Warren, C.R., 2014. Organic $\mathrm{N}$ molecules in the soil solution: what is known, what is unknown and the path forwards. Plant Soil 375, 1-19.

Weigelt, A., Bol, R., Bardgett, R.D., 2005. Preferential uptake of soil nitrogen forms by grassland plant species. Oecologia 142, 627-635.

Wiener, G., Jianlin, H., Ruijun, L., 2003. The yak. FAO Regional Office for Asia and the Pacific.

Wu, H., Dannenmann, M., Fanselow, N., Wolf, B., Yao, Z., Wu, X., Brüggemann, N., Zheng, X., Han, X., Dittert, K., 2011. Feedback of grazing on gross rates of N mineralization and inorganic N partitioning in steppe soils of Inner Mongolia. Plant Soil 340, 127-139. 
636

637

638

639

640

641

642

643

644

645

646

647

648

649

650

651

652

653

654

655

656

657

Wu, Y.B., Wu, J., Deng, Y.C., Tan, H.C., Du,Y.G., Gu, S., Tang, Y.H., Cui, X.Y., 2011. Comprehensive assessments of root biomass and production in a Kobresia humilis meadow on the Qinghai-Tibetan Plateau. Plant Soil 338, 497-510.

Xu, X.L., Ouyang, H., Kuzyakov, Y., Richter, A., Wanek, W., 2006. Significance of organic nitrogen acquisition for dominant plant species in an alpine meadow on the Tibet plateau, China. Plant Soil 285, 221-231.

Xu, X.L., Ouyang, H., Richter, A., Wanek, W., Cao, G., Kuzyakov, Y., 2011. Spatio-temporal variations determine plant-microbe competition for inorganic nitrogen in an alpine meadow. J. Ecol. 99, 563-571.

Kuzyakov, Y., Xu, X.L., 2013. Competition between roots and microorganisms for nitrogen: mechanisms and ecological relevance. New Phytol. 198, 656-669.

Kimball, B.A., Conley, M.M., Wang, S., Lin, X., Luo, C., Morgan, J., Smith, D., 2008. Infrared heater arrays for warming ecosystem field plots. Glob. Chan. Biol. 14, $309-320$.

Yao, J., Yang, B.H., Yan, P., Liang, C., Jiao, S., Lang, X., Guo, X., Feng, R., Cheng, S., 2006. Analysis on habitat variance and behaviour of Bos gruiens in China. Acta Prat. Sin. 15,124.

Yu, Z., Zhang, Q., Kraus, T.E.C., Dahlgren, R.A., Anastasio, C., Zasoski, R.J., 2002. Contribution of amino compounds to dissolved organic nitrogen in forest soils. Biogeochemistry 61, 173-198.

Zhu, T., Cheng, S., Fang, H., Yu, G., Zheng, J., Li, Y., 2011. Early responses of soil $\mathrm{CO}_{2}$ emission to simulating atmospheric nitrogen deposition in an alpine meadow 

on the Qinghai Tibetan Plateau. Acta Ecol. Sin. 31, 2687-2696. 